\title{
Influence of Copper and Biopolymer/Saqez Resin on the Properties of Poplar Wood
}

\author{
Huijun Dong ${ }^{1}$, Mohsen Bahmani ${ }^{2, *}$, Sohrab Rahimi ${ }^{3}$ and Miha Humar ${ }^{4}$ (i) \\ 1 College of Material Science and Engineering, Nanjing Forestry University, Nanjing 210037, China; \\ donghuijun@njfu.edu.cn \\ 2 Department of Natural Resources and Earth Science, Shahrekord University, Shahrekord 64165478, Iran \\ 3 Department of Wood Science, University of British Columbia, Vancouver, BC V6T 1Z4, Canada; \\ sohrab.rahimi@alumni.ubc.ca \\ 4 Department of Wood Science, Biotechnical Faculty, University of Ljubljana, 1501 Ljubljana, Slovenia; \\ miha.humar@bf.uni-lj.si \\ * Correspondence: mohsen.bahmani@sku.ac.ir; Tel.: +98-3832324401
}

Received: 6 May 2020; Accepted: 10 June 2020; Published: 11 June 2020

\begin{abstract}
There is an increasing trend in the use of environmentally-friendly materials in wood protection. This includes the use of less toxic active ingredients, as well as better fixation. This study investigates the formulation based on the combination of copper and Saqez resin on the physical and biological resistance properties of poplar wood. Samples were treated by either copper-ethanolamine $(\mathrm{Cu} / \mathrm{MEA})$ and/or Saqez resin at various treatment levels. A vacuum pressure procedure was applied. The retention, weight percent gain, water absorption, volumetric swelling, and decay resistance of the samples were then determined. The highest retention and weight percent gain were obtained in the samples treated with the combination of copper-based system and Saqez resin. Additionally, the combination of the copper and Saqez improved the physical properties and decay-resistance against white-rot fungus Trametes versicolor.
\end{abstract}

Keywords: Saqez; copper; physical properties; biological resistance; performance

\section{Introduction}

Wood, as a versatile biocomposite material, has had a wide variety of applications, such as furniture, construct structures, artifacts, toolmaking, for several centuries [1]. However, the application of less durable wood species in outdoor applications is frequently limited [2]. Namely, wood is susceptible to decay by wood-destroying organisms, such as fungi and insects. Predominant hygroscopicity, resulting from the presence of the abundant hydroxyl groups in wood, renders it susceptible to fungal infestation. Wood and wood-based products often need treatments with preservatives to increase durability and achieve the desired service life [3-6]. One effective method to improve the bio-resistance features of wood and wood-based products is the utilization of natural substances, such as plant essential oils and resins $[7,8]$. There is an ever-increasing interest in the application of essential oils due to their natural safety and environmentally friendly aspects. They are effective against bacteria [9,10], fungi and molds [11-15], and insects [16,17]. Su et al. [18] found that the essential oils of Eucalyptus citriodora can prevent the growth of fungi and molds. Yang and Clausen [19] obtained mold inhibition on southern yellow pine by geranium and thyme oil. Mohareb et al. [20] monitored the antifungal activity of 18 essential oils from Egyptian plants against wood-decay fungi and concluded that the essential oils of Cupressus sempervirens, Citrus limon, Thuja occidentalis, Schinus molle, A. monosperma, and Pelargonium graveolens were the most potent inhibitors against fungi. Bahmani and Schmidt [21] studied 16 essential oils against wood decay fungi and molds and found lavender oil, lemongrass oil, and thyme oil to 
be the most effective against mold and wood decay fungi. However, although these oils improve the overall performance of wood, they are hardly classified as wood preservatives, as biocides have to pass strict efficacy and eco-toxicity assessment, prescribed by authorization agencies, such as European Chemicals Agency (ECHA) in EU.

Nevertheless, the use of plant essential oils in wood protection has some limitations. Applications of the natural oils have some restrictions a due to their high volatility, insufficient fixation, and leaching from treated wood if the oils are not combined with fixatives. The conjunction of natural oils with other biocides, such as copper compounds, have been proposed for overcoming deficiencies of environmentally friendly preservatives, such as natural oils, and may be able to improve their efficacy against fungi and insects. Alfredsen and Flaete [22] obtained tall oil combined with copper that can provide some protection for treated wood. Can and Sivrikaya [23] investigated the combination treatment of tall oil and linseed and copper on some properties of pine wood. They concluded that copper and oil combination could improve the physical and biological properties of wood as well as decrease copper leaching.

Copper $(\mathrm{Cu})$ is one of the most effective and extensively used wood biocide. It can be effective against wood-decaying fungi and some termites if applied in sufficient quantities [24]. Copper-based preservatives are traditionally applied for the protection of posts, bridges, vineyard poles, noise barriers, fences, etc. In the past, copper was mixed with chromium compounds in chromated copper arsenate compounds (CCA). Nowadays, CCA treatment is forbidden in Europe and the United State-for many applications, mainly due to the end of life issues. The alternatives to these biocides are various organic-based substances, such as ammoniacal copper quaternary (ACQ) copper azole (CA), and bis-(n-cyclohexyldiazeniumdioxy)-copper (CuHDo) [25]. Copper-based preservatives are usually combined with ethanolamine to improve fixation and enable better penetration [26]. Copper azole preservatives are one of the most important solutions for wood preservation [27]. It is commercially available for residential applications, free of arsenic and chromium, and able to be applied in above-ground, ground contact, and freshwater applications. However, high levels of copper and relatively high formulation cost [28], as well as copper release and disposal issues in the treated wood, are recognized to be the main limitation for future use [29]. Moreover, Copper azole belongs to the water-borne preservatives group, and treated wood suffers from poor dimensional stability [30]. To enhance the water repellent properties of copper azole-treated wood, adding hydrophobic materials, such as rosin solutions, coating compounds, etc., is needed.

One of the most economically important non-wood forest products of Zagros forests in the west of Iran is pistachio tree resin known as "Saqez". Saqez is used for a wide variety of industrial and traditional applications, such as food and pharmaceutical formulation [31]. Saqez is a semi-dense, adhesive, liquid resin comprising antioxidants, has antimicrobial, antibacterial, and antifungal properties, and is applied in the preparation of ointments for skin disorders [32,33]. The increasing request in wood protection technology for safe, low cost, sustainable, environmental, natural, and biodegradable preservatives has convinced scientists and technologists to examine new sources of natural materials as substitutes for chemical ones. Populus (poplar) tree species, including hybrid varieties, are cultivated as a fast-growing bioenergy crop, but can also be utilized to produce wood and derived materials. Poplar wood was chosen as it is one of the most important plantation species [34]. One of the most significant disadvantages of poplar wood that limits its usability is low natural durability [35]. The respective study aims to improve the durability and water performance of poplar wood with pistachio tree resin (Saqez) alone or combined with copper-ethanolamine $(\mathrm{Cu} / \mathrm{MEA})$ and Saqez.

\section{Material and Methods}

\subsection{Material}

The boards were cut from the trunks of three 23-year-old poplar trees (Populus deltoids) located in the Khirod area (Mazandaran province, Northern part of Iran). and air-dried. Wood samples 
were cut from the boards for the various tests. All samples were free of defects, such as knots, resin pockets, and fungal infections. The wood sample sizes for the physical tests were $20_{\mathrm{l}} \times 20_{\mathrm{r}} \times 20_{\mathrm{t}}$ $\mathrm{mm}^{3}$, according to ISO 13061:2016 [36]. Five replicates were cut for each test, along with five replicate control samples. For fungal durability studies, the sample size was $50_{\mathrm{l}} \times 25_{\mathrm{r}} \times 15_{\mathrm{t}} \mathrm{mm}^{3}$ [37] with five replicates. For the respective experiments, five samples were chosen, as prescribed by the respective standard. The experiment was rather long-lasting, and the capacities of the incubation chambers were limited, which limited the replicates numbers. Besides, the response of the respective fungal strains to the treatment was rather uniform, as seen from the deviations of the mass loss. Before treatment, samples were oven-dried $\left(103^{\circ} \mathrm{C}, 24 \mathrm{~h}\right)$, to obtain constant moisture content and to determine their initial masses. The density of the oven-dried specimens was in the range of $(460 \pm 20) \mathrm{kg} / \mathrm{m}^{3}$. To ensure maximum uptake of the treatment solutions, none of the surfaces of the wood samples was sealed. The copper-containing wood preservative used in this study was copper-ethanolamine $(\mathrm{Cu} / \mathrm{MEA})$, which consisted of $\mathrm{CuCO}_{3}$ (Merck) and ethanolamine $\left(\mathrm{C}_{2} \mathrm{H}_{7} \mathrm{NO}\right)$. The resin of wild pistachio (Pistacia atlantica) trees called "Saqez" was obtained from the area located in Charmahal and Bakhtiari province, Southwest of Iran.

\subsection{Methods}

Before the treatment process, samples were divided into three groups. The first group was treated with copper-ethanolamine $(\mathrm{Cu} / \mathrm{MEA})$. The copper concentration was $0.5 \%$ in all tests. This concentration is usually sufficient for the protection of wood in-ground applications. The second group was treated with various concentrations of $(5 \%, 10 \%$, and 15\%) pistachio tree resin. Ethanol, with $96 \%$ purity, was used in the preparation of the resin. The third group was initially impregnated with copper amine-based wood preservative and afterward treated with resin at a concentration of 15\% (Table 1).

Table 1. Experimental design of the study.

\begin{tabular}{cccc}
\hline & \multirow{2}{*}{ Test Groups } & \multicolumn{2}{c}{ Preservative Solution (\%) } \\
\cline { 3 - 4 } & & Cu (\%) & Saqez Resin (\%) \\
\hline A & Control & 0 & 0 \\
B & Copper/MEA & $0 / 5$ & 0 \\
& & 0 & 5 \\
C & Saqez & 0 & 10 \\
& & 0 & 15 \\
D & Copper/MEA + Saqez & $0 / 5$ & 15 \\
\hline \multicolumn{2}{c}{$*$ Copper-ethanolamine. }
\end{tabular}

For treatments, a vacuum pressure impregnation was applied in a pilot plant, whereby the vacuum of 0.8 bar lasted for $30 \mathrm{~min}$, followed by pressure at 4 bar for $120 \mathrm{~min}$. After that, samples were stored for two weeks in the lab ambiance for evaporation of the solvent. The retentions for each treatment were calculated according to the Equation (1):

$$
\mathrm{R}=\frac{G \times C}{V} \times 100 \mathrm{~kg} \mathrm{~m}^{-3}
$$

where $G$ is the amount of treating solution absorbed the samples $(\mathrm{kg}) ; C$ is the concentration of the solution (\%), and $V$ is the volume of the samples $\left(\mathrm{m}^{3}\right)$.

After treatment, the oven-dry $\left(103^{\circ} \mathrm{C}\right.$ for $\left.24 \mathrm{~h}\right)$ weight of all samples was evaluated and used to calculate the weight percent gain (WPG) (Equation (2)):

$$
W P G(\%)=\frac{M_{2}-M_{1}}{M_{1}} \times 100
$$

where $M_{2}$ is the sample weight after treatment, and $M_{1}$ is the sample weight before treatment. 


\subsubsection{Water Absorption and Volumetric Swelling Measurements}

Water absorption and volumetric swelling tests were carried out by soaking the treated and untreated samples for 2, 4, 6, 8, $24 \mathrm{~h}$, and repeated at $24 \mathrm{~h}$ intervals at room temperature following ISO 13061:2016 [36]. The water was replaced with fresh. Water absorption and volumetric swelling were evaluated according to Equations (3) and (4), respectively:

$$
W A(\%)=\frac{\left(W_{1}-W_{0}\right)}{W_{0}} \times 100
$$

where $W A$ is water absorption (\%), $W_{1}$ is the weight of samples after immersion, $W_{0}$ is the oven-dried weight before immersion.

$$
\operatorname{VS}(\%)=\frac{\left(\mathrm{V}_{1}-\mathrm{V}_{0}\right)}{\mathrm{V}_{0}} \times 100
$$

where VS is volume swelling (\%), $V_{1}$ is the volume of samples after immersion, and $V_{0}$ is the volume of samples before immersion.

\subsubsection{Biological Durability}

The European EN 84 standard [38] describes a method for artificial aging (leaching) of wood before testing the biological effectiveness. This standard was designed to simulate extensive leaching by natural precipitation. The first step was impregnation with demineralized water. The samples were stacked in a container, weighed down, and vacuum impregnated ( $4 \mathrm{kPa})$ with demineralized water for $20 \mathrm{~min}$ and soaked for an additional $2 \mathrm{~h}$. Samples were then immersed in water for 14 days, and during this period, water was replaced nine times. Biological durability was evaluated on both leached and unbleached samples in accordance with the European method [37] to assess the resistance to white-rot fungus. The decay chambers were Petri dishes containing $4.8 \%$ malt extract agar (Merck, Darmstadt, Germany) that were inoculated with an agar plug cut from an actively growing culture of Trametes versicolor (L.: Fr.) Pilát, strain CTBA 863 from France, derived from the strain collection of the University of Hamburg. Wood samples were oven-dried at $103 \pm 3{ }^{\circ} \mathrm{C}$ for $24 \mathrm{~h}$ and weighed before fungal exposure. The treated and untreated samples were subjected to the respective fungi by placing them on mycelia grown in the Petri dishes. The wood samples were incubated for 16 weeks at $23^{\circ} \mathrm{C}$ and $65 \pm 5 \%$ relative humidity. At the end of exposure time, the mycelia coverings on the sample surfaces were removed and weighed. After exposure, surface mycelium was scraped off, and wood samples were dried at $103{ }^{\circ} \mathrm{C}$ for $24 \mathrm{~h}$ and weighed again to calculate the mass loss according to Equation (5):

$$
\operatorname{ML}(\%)=\frac{\mathrm{M}_{0}-\mathrm{M}_{1}}{\mathrm{M}_{0}} \times 100
$$

where $\mathrm{ML}$ is the mass loss (\%), $\mathrm{M}_{0}$ is the oven-dry weight of the sample before fungi test (g), and $\mathrm{M}_{1}$ is the oven-dried weight after fungi test $(\mathrm{g})$.

\subsubsection{Statistical Analysis}

The obtained data were subjected to the analysis of variance (ANOVA) using SPSS Version 25.0, (IBM SPSS Statistics for Windows, IBM Corporation, Armonk, NY, USA). All data checked for normality requirement with a Shapiro-Wilks test. Bootstrapping and robust homogenous groups were used. Means were analyzed and grouped using Duncan's multiple range test (DMRT).

\section{Result and Discussion}

Populus deltoids was chosen for this study because it is used prevalently in a wide variety of applications in Asia, Europe, and America. The majority of this wood is used for energetic purposes, composites, veneers, packaging [34]. However, the industry is looking for applications with higher added value as well, such as furniture, decking, etc. If poplar wood is to be used in more exposed 
applications, it has to be protected to limit fungal decay [39]. The retention of preservatives is the first substantial factor that shows the quality of the impregnation. Retention of the active ingredients increased with increasing resin concentration (Figure 1). Namely, wood treated with the lowest concentration of resin retained $18.4 \mathrm{~kg} / \mathrm{m}^{3}$ of the resin, while the samples that were treated with the highest concentration of the resin system, took up $74.5 \mathrm{~kg} / \mathrm{m}^{3}$ of the resin. It seems that ethanol solution has sufficient viscosity that enables good penetration into wood. ANOVA test results indicated that there was a significant difference between the retention of preservatives at the $99 \%$ confidence interval $(p<0.01)$ (Table 2). Duncan's test classified the value of retentions into four groups.

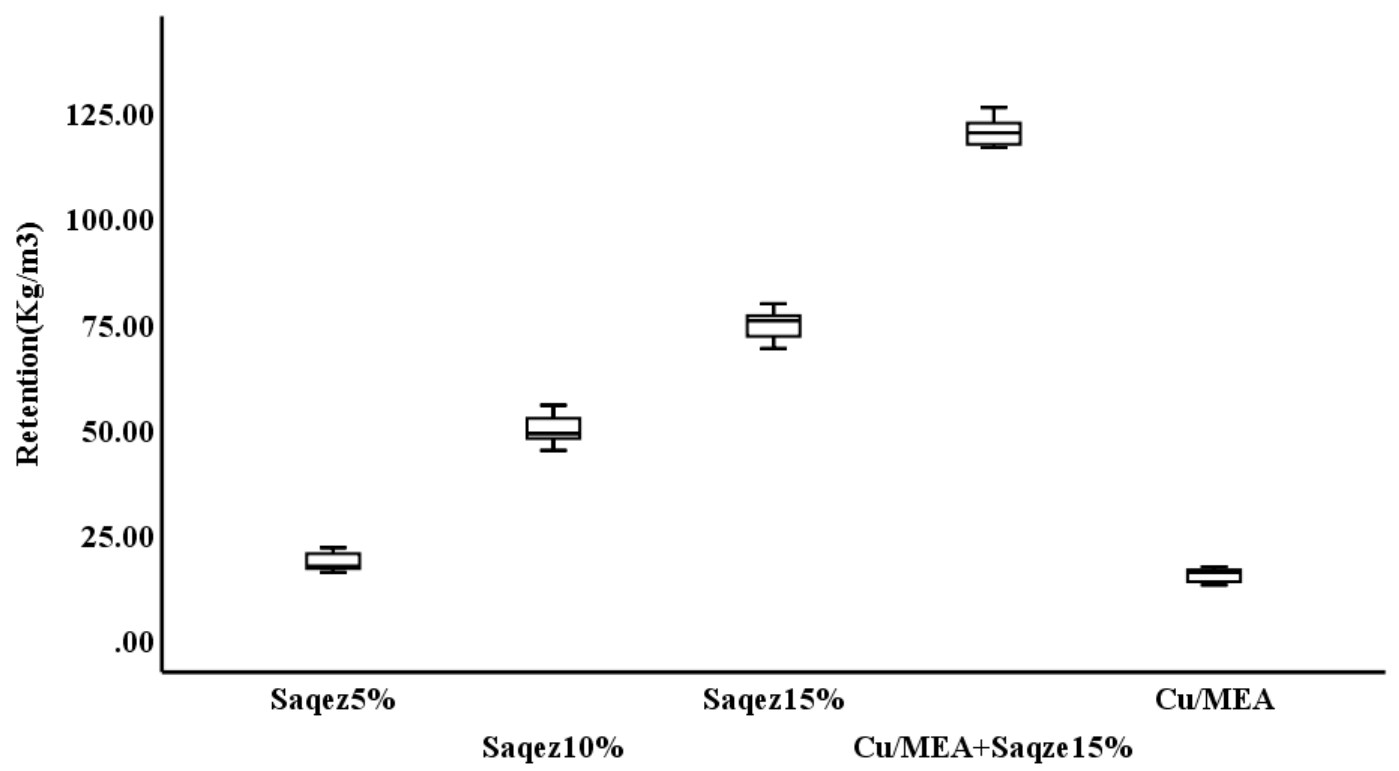

Figure 1. Boxplot of wood preservative retention in the treated wood samples.

Table 2. Analysis of variance and Duncan's multiple range test (DMRT) for preservative retention in the treated wood samples.

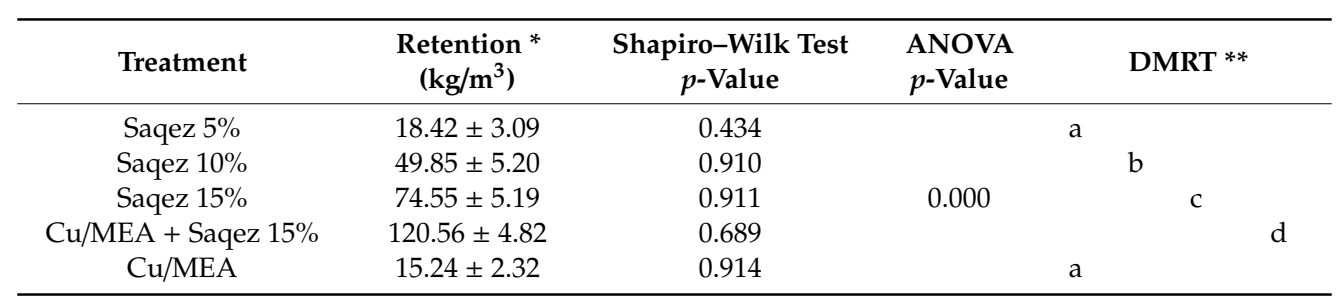

${ }^{*}$ Retention as average \pm robust confidence interval. ${ }^{* *}$ Means with the same letter are not significantly different according to DMRT.

The highest retentions were observed at samples that were first treated with the copper-based system and in the later stage with the resin-based system. These kinds of impregnations are called dual treatments and are reported in the literature already [40]. Retention of wax into the copper-ethanolamine based system was higher than non-copper treated wood. It can be assumed that one of the possible reasons for this occurrence could be assigned to the wood swelling efficacy of ethanolamine [41].

Wood retention data were in line with WPG data. In general, WPG increased with increasing resin concentration. Similarly, as reported for retention data, the highest WPG was determined in samples treated with copper-ethanolamine solution subsequently treated with resin (Figure 2). High WPG can be ascribed to the reaction of copper-ethanolamine complexes with wood and resin [42]. However, negative WPG was determined in samples treated with the lowest concentration of the resin. This can be ascribed to the fact that there might be some extractives leached from wood during impregnation with the ethanol-based solution. Besides, part of the resin might evaporate from the wood during oven drying. Predominately, the melting point of the resin was rather low. The melting point was between 
$50{ }^{\circ} \mathrm{C}$ and $60^{\circ} \mathrm{C}$. ANOVA test results showed that there was a significant difference between the WPG of samples $(p<0.01)$ (Table 3). Duncan's test classified the value of WPG into five groups.

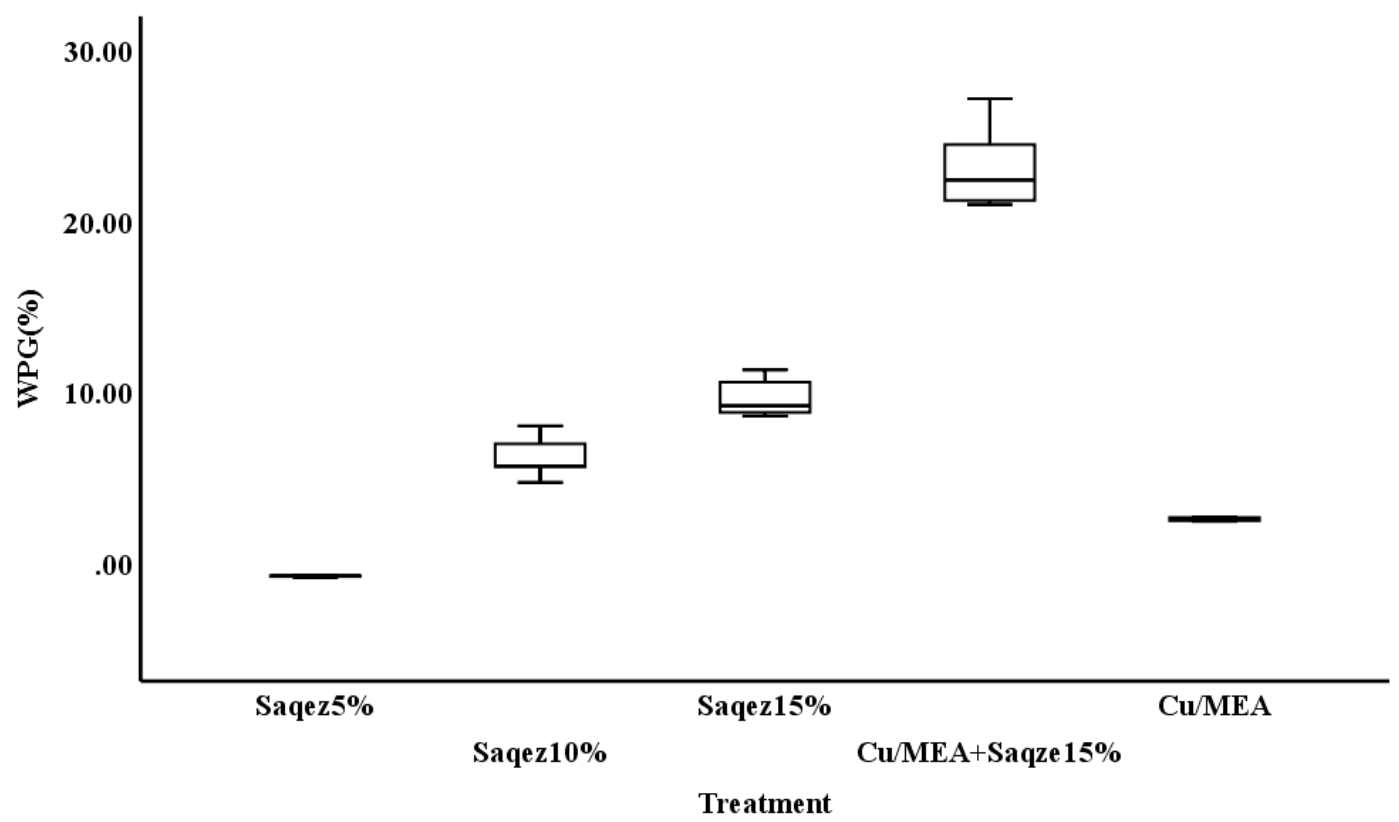

Figure 2. Weight percent gain values in the wood samples.

Table 3. Analysis of variance and Duncan's multiple range test (DMRT) weight percent gains in the treated wood samples.

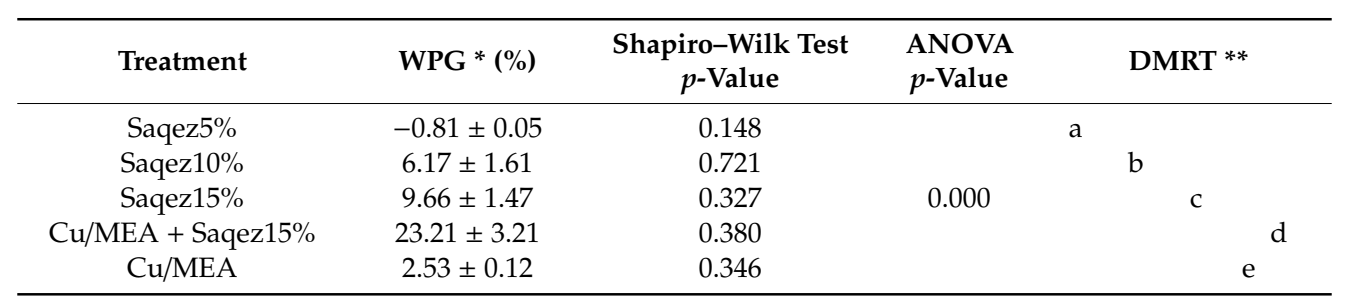

* WPG as average \pm robust confidence interval. ${ }^{* *}$ Different letters show a significant difference at $5 \%$ probability, according to DMRT.

Recent studies clearly indicate that the performance of wood in above-ground outdoor applications is a function of inherent durability (presence of biologically active extractives and/or fungicides) and water exclusion efficacy (the ability of wood to remain dry) [43]. Therefore, studies of water ability are essential. In addition, water repellents can slow down copper leaching [44]. As can be resolved from Figure 3, resin impregnation had a positive effect on water performance. Wood treated with resins took up less water than control wood. This can be ascribed to the lumen filling as well as to the hydrophobic nature of the resins. A rather notable difference was evident from the beginning. Water repellency increased with increasing retention. The moisture content of wood treated with $5 \%$ concentration of resin was $25.2 \%$, while the MC of the samples treated with copper and $15 \%$ ethanol concentration of Saqez resulted in an MC of $14.1 \%$.

Figure 4 shows a good correlation between volumetric swelling and wood MC. That which exhibited good water exclusion efficacy exhibited good dimensional stability. The influence of the retention on wood swelling was even more prominent than on wood moisture content. In contrast to wood MC, the differences between treatments increased with immersion time. Thus, the highest difference was noted at the end of the $192 \mathrm{~h}$ lasting immersion. Namely, swelling of control samples was $26.7 \%$, while swelling of samples treated with a combination of copper and Saqez resin resulted in swelling of $13.3 \%$. 


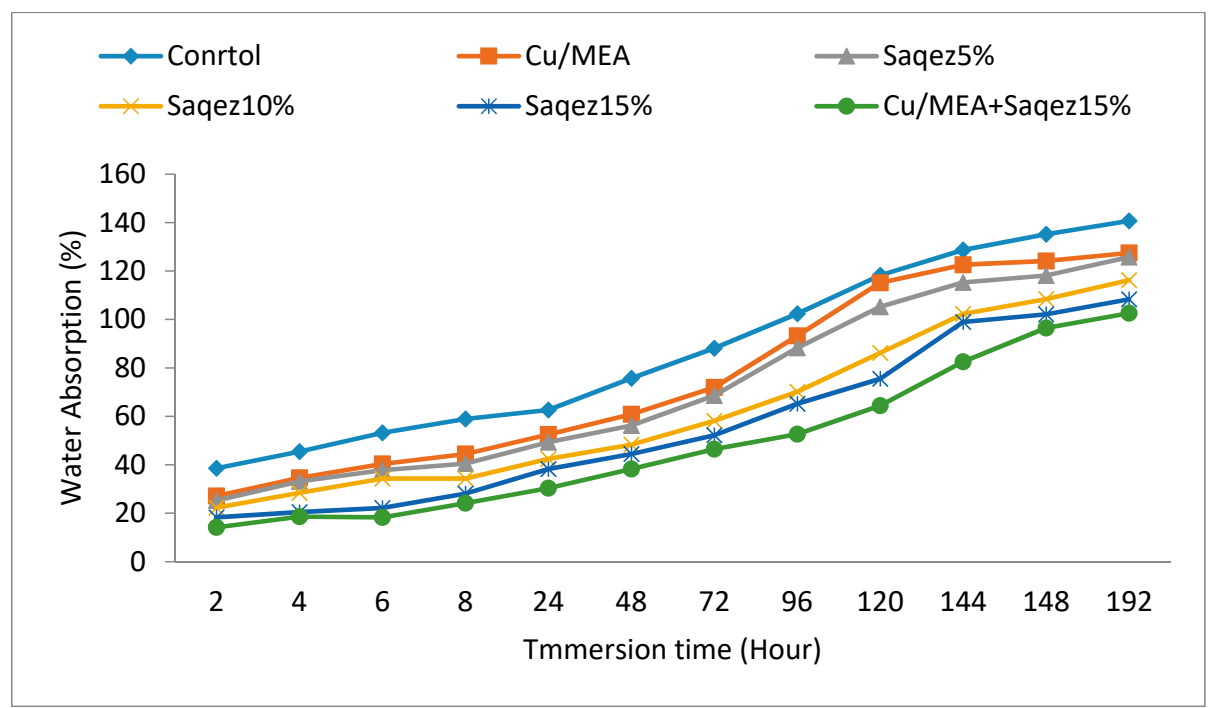

Figure 3. Water absorption in the wood samples.

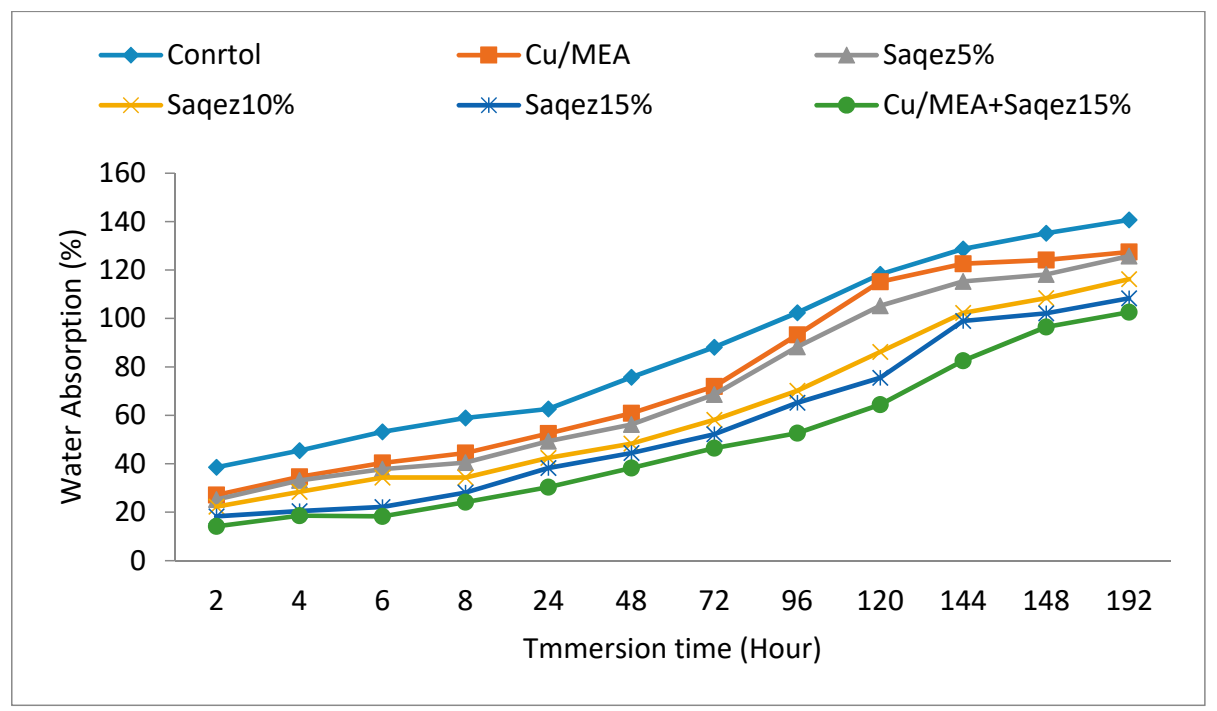

Figure 4. Volumetric swelling in the wood samples.

One of the prime objectives of this study was to determine the performance of the respective treatment against wood decay fungi. Samples were exposed to white-rot fungi. White rot fungi are the most important organisms degrading hardwoods [45]. Mass loss of the leached and unleached samples was rather high, ranging between $39.3 \%$ at non-leached and $44.8 \%$ at leached specimens (Figure 5). These data are in line with the low durability classification of poplar wood [35]. Resins have a limited effect on the fungi. Mass loss of the Saqez treated samples was a bit lower than the mass loss of the controls. The efficacy of the resin increased with increasing concentration of resin in the treatment solution. For example, the mass loss of the wood treated with $5 \%$ ethanol solution of Saqez was $30.1 \%$, whereas the mass loss of the wood treated with a similar solution with three times higher concentration was $20.4 \%$. This mass loss was higher than the mass loss of the comparable oil or wax-based systems [12,46]. The major constituents in the Saqez are $\alpha$-pinene $(60.15 \%), \beta$-pinene $(8.68 \%)$, and $\alpha$-terpinene (3.94\%) [47,48]. The antifungal activity of Saqez resin could be related to the respective components. Antifungal activity of $\alpha$-pinene, $\beta$-pinene, and $\alpha$-terpinene was indicated in previous studies [49-51]. Duncan's test grouped the value of mass loss into four groups (Table 4). 


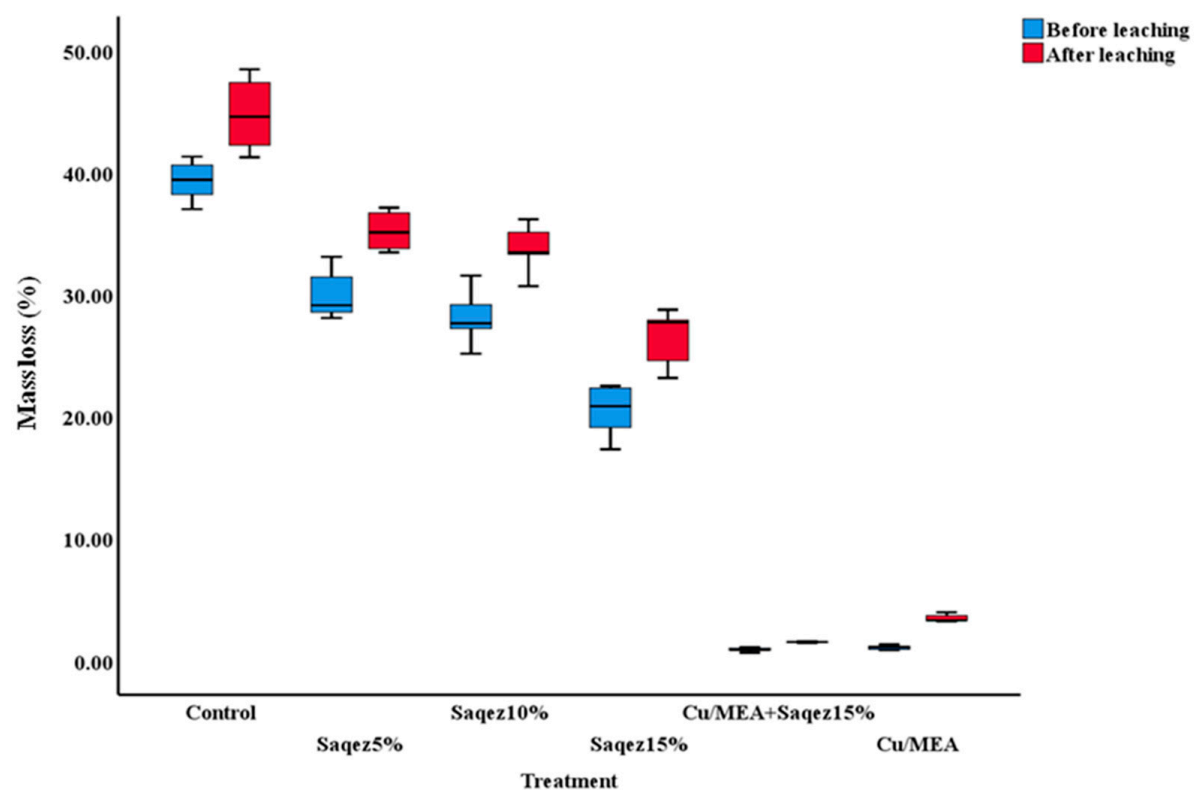

Figure 5. Mass loss of wood samples subjected to Trametes versicolor.

Table 4. Analysis of variance and Duncan's multiple range test (DMRT) for Mass loss in untreated and treated wood samples.

\begin{tabular}{|c|c|c|c|c|c|c|}
\hline Leaching Test & Treatment & Mass Loss * $(\%)$ & $\begin{array}{l}\text { Shapiro-Wilk } \\
\text { Test } p \text {-Value }\end{array}$ & ANOVA $p$-Value & & DMRT ** \\
\hline \multirow{6}{*}{ Before Leaching } & Control & $39.30 \pm 2.17$ & 0.86 & \multirow{6}{*}{0.000} & $\mathrm{a}$ & \multirow{6}{*}{$b$} \\
\hline & Saqez $5 \%$ & $30.06 \pm 2.64$ & 0.37 & & & \\
\hline & Saqez10\% & $28.15 \pm 2.95$ & 0.94 & & & \\
\hline & Saqez15\% & $20.43 \pm 2.74$ & 0.49 & & & \\
\hline & $\mathrm{Cu} / \mathrm{MEA}+$ Saqez15\% & $0.92 \pm 0.21$ & 0.72 & & & \\
\hline & $\mathrm{Cu} / \mathrm{MEA}$ & $1.10 \pm 0.23$ & 0.84 & & & \\
\hline \multirow{6}{*}{ After leaching } & Control & $44.77 \pm 3.88$ & 0.58 & \multirow{6}{*}{0.000} & a & \multirow{6}{*}{$\begin{array}{l}\mathrm{b} \\
\mathrm{b}\end{array}$} \\
\hline & Saqez $5 \%$ & $35.22 \pm 2.05$ & 0.39 & & & \\
\hline & Saqez $10 \%$ & $33.74 \pm 2.58$ & 0.80 & & & \\
\hline & Saqez15\% & $26.43 \pm 2.99$ & 0.29 & & & \\
\hline & $\mathrm{Cu} / \mathrm{MEA}+$ Saqez15\% & $1.55 \pm 0.051$ & 0.98 & & & \\
\hline & $\mathrm{Cu} / \mathrm{MEA}$ & $3.51 \pm 0.40$ & 0.18 & & & \\
\hline
\end{tabular}

* Mass loss as average \pm robust confidence interval. ${ }^{* *}$ Means with the same letter are not significantly different.

The presence of copper in wood slowed down wood decay considerably. Leaching reduced the influence of the copper-based system, predominately as there were no secondary fungicides present [52]. However, as can be seen from the comparison of mass losses of leached and non-leached copper and copper-Saqez treated wood, a combination of copper and Saqez acted synergistically. At the moment, we cannot conclude whether this is because of the limited effect of Saqez resin on the fungi, or due to the limited copper leaching.

\section{Conclusions}

The synergistic effect between copper and Saqez was investigated. Saqez had a positive influence on water performance. Wood treated with Saqez exhibited better water performance, which was reflected in better dimensional stability and likely limited copper leaching as well. The impregnation of wood with Saqez was not sufficient to limit fungal decay. However, the combination of copper-ethanolamine based wood preservatives with Saqez had a positive effect on copper efficacy against wood decay fungi.

Author Contributions: Co-writing and editing, M.B., H.D.; Designing and performing experiments, and writing the original paper, S.R.; Analyzing data and editing, M.H.; Writing-review and editing. All authors have read and agreed to the published version of the manuscript.

Funding: This research received no external funding. 
Conflicts of Interest: The authors declare no conflict of interest.

\section{References}

1. Cheung, K.C.K. Wooden structures. In Reference Module in Materials Science and Materials Engineering; Elsevier: Amsterdam, The Netherlands, 2019; Volume 1, pp. 1-14.

2. Kutnik, M.; Suttie, E.; Brischke, C. European standards on durability and performance of wood and wood-based products-Trends and challenges. Wood Mater. Sci. Eng. 2014, 9, 122-133. [CrossRef]

3. Lebow, S. Leaching of Wood Preservative Components and Their Mobility in the Environment: Summary of Pertinent Literature; General Technical Report FPL-GTR-93; US Department of Agriculture: Madison, WI, USA, 2006.

4. Bahmani, M.; Fromm, J.; Schmidt, O.; Melcher, E. Residual metal content and metal distribution in chromium/copper-treated wood after field and laboratory leaching exposure. Eur. J. Wood Prod. 2015, 73, 377-384. [CrossRef]

5. Bahmani, M.; Melcher, E.; Schmidt, O.; Fromm, J. Influence of exposure time, wood species and dimension on the remaining copper and chromium content in CC-treated wood after field and laboratory leaching tests. Holzforschung 2015, 69, 1143-1150. [CrossRef]

6. Casado-Sanz, M.M.; Silva-Castro, I.; Ponce-Herrero, L.; Martín-Ramos, P.; Martín-Gil, J.; Acuña-Rello, L. White-rot fungi control on Populus spp. wood by pressure treatments with silver nanoparticles, chitosan oligomers and propolis. Forests 2019, 10, 885. [CrossRef]

7. Žlahtič, M.; Mikac, U.; Serša, I.; Merela, M.; Humar, M. Distribution and penetration of tung oil in wood studied by magnetic resonance microscopy. Industr. Crop Prod. 2017, 96, 149-157. [CrossRef]

8. Woźniak, M.; Kwaśniewska-Sip, P.; Waśkiewicz, A.; Cofta, G.; Ratajczak, I. The possibility of propolis extract application in wood protection. Forests 2020, 11, 465. [CrossRef]

9. Burt, S. Essential oils: Their antibacterial properties and potential applications in foods-A review. Int. J. Food Microbiol. 2004, 94, 223-253. [CrossRef] [PubMed]

10. Wong, S.Y.Y.; Grant, R.I.; Friedman, M.; Elliott, C.; Situ, C. Antibacterial activities of naturally occurring compounds against Mycobacterium avium subsp. paratuberculosis. Appl. Environ. Microbiol. 2008, 74, 5986-5990. [CrossRef]

11. Singh, T.; Singh, A. A review on natural products as wood protectant. Wood Sci. Technol. 2012, 46, 851-870. [CrossRef]

12. Humar, M.; Lesar, B. Efficacy of linseed- and tung-oil-treated wood against wood-decay fungi and water uptake. Int. Biodeterior. Biodegrad. 2013, 85, 223-227. [CrossRef]

13. Pánek, M.; Reinprecht, L.; Hulla, M. Ten essential oils for beech wood protection. Efficacy against wood-destroying fungi and moulds, and effect on wood discoloration. BioResources 2014, 9, 5588-5603. [CrossRef]

14. De Medeiros, F.C.; Gouveia, F.N.; Bizzo, H.R.; Vieira, R.F.; Del Menezzi, C.H. Fungicidal activity of essential oils from Brazilian Cerrado species against wood decay fungi. Int. Biodeterior. Biodegrad. 2016, 114, 87-93. [CrossRef]

15. Fidah, A.; Salhi, N.; Rahouti, M.; Kabouchi, B.; Ziani, M.; Aberchane, M.; Famiri, A. Natural durability of Cedrus atlantica wood related to the bioactivity of its essential oil against wood decaying fungi. Maderas Cienc. Tecnol. 2016, 18, 567-576. [CrossRef]

16. Isman, M.B.; Miresmaill, S.; MacHial, C. Commercial opportunities for pesticides based on plant essential oils in agriculture, industry and consumer products. Phytochem. Rev. 2011, 10, 197-204. [CrossRef]

17. Fatima, R.; Morrell, J.J. Ability of plant-derived oils to inhibit dampwood termite (Zootermopsis augusticollis) activity. Maderas Cienc. Tecnol. 2015, 17, 685-690. [CrossRef]

18. Su, Y.C.; Ho, C.L.; Wang, E.I.C.; Chang, S.T. Antifungal activities and chemical compositions of essential oils from leaves of four eucalypts. Taiwan Lin Ye Ke Xue 2006, 21, 49-61.

19. Yang, V.W.; Clausen, C.A. Moldicidal Properties of Seven Essential Oils; Technical Report No. 06-30404; IRG Secretariat: Stockholm, Sweden, 2006.

20. Mohareb, A.S.; Badawy, M.E.; Abdelgaleil, S.A. Antifungal activity of essential oils isolated from Egyptian plants against wood decay fungi. J. Wood Sci. 2013, 59, 499-505. [CrossRef]

21. Bahmani, M.; Schmidt, O. Plant essential oils for environment-friendly protection of wood objects against fungi. Maderas Cienc. Tecnol. 2018, 20, 325-332. [CrossRef] 
22. Alfredsen, G.; Flaete, P.O. Tall oil performance after a decade of field exposure. In Proceedings of the Annual Meeting of the International Research Group on Wood Protection, Viña del Mar, Chile, 10-14 May 2015; p. 30672.

23. Can, A.; Sivrikaya, H. Combined effects of copper and oil treatment on the properties of Scots pine wood. Drewno Prace Naukowe Doniesienia Komunikaty 2017, 60, 89-103.

24. Dhyani, S.; Kamdem, D.P. Bioavailability and form of copper in wood treated with copper-based preservative. Wood Sci. Technol. 2012, 46, 1203-1213. [CrossRef]

25. Pankras, S.; Cooper, P.A.; Wylie, S. Relationship between copper species in solution and leaching from alkaline copper quat (ACQ) treated wood. Holzforschung 2012, 66, 505-514. [CrossRef]

26. Lee, M.J.; Cooper, P.A. Copper precipitation of Cu-monoethanolamine preservative in wood. Holzforschung 2012, 66, 1017-1024. [CrossRef]

27. Humar, M.; Pohleven, F.; Žlindra, D. Influence of water, properties on leaching of copper-based preservatives from treated wood. Wood Res. 2006, 51, 69-76.

28. Freeman, M.H.; Nicholas, D.D.; Schultz, T.P. Nonarsenical wood protection: Alternatives for chromated copper arsenate, creosote and pentachlorophenol. In Environmental Impacts of Treated Wood; Townsend, T.G., Solo-Gabriele, H., Eds.; CRC/Taylor and Francis: Boca Raton, FL, USA, 2006; pp. 19-36.

29. Schultz, T.P.; Nicholas, D.D.; McIntyre, C.R. Recent patents and developments in biocidal wood protection systems for exterior applications. Recent Pat. Mater. Sci. 2008, 1, 128. [CrossRef]

30. Wang, J.; Zhong, H.; Ma, E.; Cao, J. Properties of wood treated with compound systems of paraffin wax emulsion and copper azole. Eur. J. Wood Prod. 2018, 76, 315-323. [CrossRef]

31. Mahdavi, A. The economic, social, and ecological impacts of wild pistachio (Pistacia atlantica Desf.) oleo-gum resin extraction cooperatives in Zagros forests, Ilam Province, Iran. For. Trees Livelihoods 2015, 24, $275-284$. [CrossRef]

32. Ghalem, B.R.; Benali, M. Antimicrobial activity determination of gum of Pistacia atlantica Desf. oil. Afr. J. Microbiol. Res. 2010, 4, 2457-2460.

33. Mousavi, R. Non-wood forest products, the utilisation, and harvesting methods in Sardasht, North West Iran. Int. J. For. Soil Eros. 2012, 2, 133-136.

34. Balatinecz, J.J.; Kretschmann, D.E. Properties and utilization of poplar wood. In Poplar Culture in North America Part A; NRC Research Press: Ottawa, QC, Canada, 2001; pp. 277-291.

35. Brischke, C.; Meyer, L.; Alfredsen, G.; Humar, M.; Francis, L.; Flæte, P.O.; Larsson-Brelid, P. Natural durability of timber exposed above ground-A survey. Dron. Ind. 2013, 64, 113-129. [CrossRef]

36. International Organization for Standardization. Physical and Mechanical Properties of Wood-Test Methods for Small Clear Wood Specimens-Part 14: Determination of Volumetric Shrinkage; ISO 13061-14:2016; ISO: Geneva, Switzerland, 2016; p. 5.

37. European Committee for Standardization (CEN). Wood Preservatives Test Method for Determining the Protective Effectiveness Against Wood Destroying Basidiomycetes Determination of the Toxic Values; CEN EN 113:1996; CEN: Brussel, Belgium, 1996; p. 28.

38. European Committee for Standardization (CEN). Wood Preservatives-Accelerated Ageing of Treated Wood Prior to Biological Testing—Leaching Procedure; CEN EN 84; CEN: Brussels, Belgium, 2002; p. 7.

39. Liu, M.; Hui, Z.; Erni, M.; Ru, L. Resistance to fungal decay of paraffin wax emulsion/copper azole compound system treated wood. Int. Biodeterior. Biodegrad. 2018, 129, 61-66. [CrossRef]

40. Treu, A.; Larnøy, E.; Militz, H. Process related copper leaching during a combined wood preservation process. Eur. J. Wood Prod. 2011, 69, 263-269. [CrossRef]

41. O'Leary, P.; Hodges, P.A. The relationship between full penetration uptake and swelling of different fluids. Wood Sci. Technol. 2001, 35, 217-227. [CrossRef]

42. Kozlevčar, B.; Humar, M.; Strauch, P.; Leban, I. Fixation of copper(II) ions in aqueous solution to lignin model compound vanillin in an absence of the nitrogen donor ligands; structural and EPR correlation. Z. Naturforsch. B 2005, 60, 1273-1277. [CrossRef]

43. Meyer-Veltrup, L.; Brischke, C.; Alfredsen, G.; Humar, M.; Flæte, P.O.; Isaksson, T.; Brelid, P.L.; Westin, M.; Jermer, J. The combined effect of wetting ability and durability on outdoor performance of wood: Development and verification of a new prediction approach. Wood Sci. Technol. 2017, 51, 615-637. [CrossRef]

44. Banks, W.B. Factors affecting the introduction of preservatives into wood. Pestic. Sci. 1972, 3, $219-227$. [CrossRef] 
45. Schmidt, O. Wood and Tree Fungi: Biology, Damage, Protection, and Use; Springer: Berlin/Heidelberg, Germany, 2006.

46. Humar, M.; Kržišnik, D.; Lesar, B.; Thaler, N.; Ugovšek, A.; Zupančič, K.; Žlahtič, M. Thermal modification of wax-impregnated wood to enhance its physical, mechanical, and biological properties. Holzforschung 2017, 71, 57-64. [CrossRef]

47. Sharifi, M.S.; Hazell, S.L. GC-MS analysis and antimicrobial activity of the essential oil of the trunk exudates from Pistacia atlantica kurdica. J. Pharm. Sci. Res. 2011, 3, 1364.

48. Mahmoud Kia, M. Heat Modification of Poplar Wood Using Rapeseed Oil Resin of Persian Turoentine for Urban Furniture Application. Ph.D. Thesis, University of Tehran, Tehran, Iran, July 2018.

49. Glisić, S.B.; Milojević, S.Z.; Dimitrijević, S.I.; Orlović, A.M.; Skala, D.U. Antimicrobial activity of the essential oil and different fractions of Juniperus communis L. and a comparison with some commercial antibiotics. J. Serb. Chem. Soc. 2007, 72, 311-320. [CrossRef]

50. Da Silva, M.R.; Brito, J.O.; Govone, J.S.; de Oliveira Machado, G.; Calil, C.; Christoforo, A.L.; Lahr, F.A.R. Chemical and mechanical properties changes in Corymbia citriodora wood submitted to heat treatment. Int. Biodeterior. Biodegrad. 2015, 5, 98-104.

51. Salem, M.Z.; Zidan, Y.E.; El Hadidi, N.M.; Mansour, M.M.; Elgat, W.A.A. Evaluation of usage three natural extracts applied to three commercial wood species against five common molds. Int. Biodeterior. Biodegrad. 2016, 110, 206-226. [CrossRef]

52. Humar, M.; Lesar, B. Fungicidal properties of individual components of copper-ethanolamine-based wood preservatives. Int. Biodeterior. Biodegrad. 2008, 62, 46-50. [CrossRef]

(C) 2020 by the authors. Licensee MDPI, Basel, Switzerland. This article is an open access article distributed under the terms and conditions of the Creative Commons Attribution (CC BY) license (http://creativecommons.org/licenses/by/4.0/). 